\title{
Micro-structural and compositional variations of hydrothermal epidote-group minerals from a peralkaline granite, Corupá Pluton, Graciosa Province, South Brazil, and their petrological implications
}

\author{
SILVIO R.F. VLACH \\ Departamento de Mineralogia e Geotectônica, Instituto de Geociências, Universidade de São Paulo, \\ Rua do Lago, 562, Cidade Universitária, 05508-080 São Paulo, SP, Brasil
}

Manuscript received on April 5, 2011; accepted for publication on November 28, 2011

\begin{abstract}
Epidote-group minerals, together with albite, quartz, fluorite, Al-poor and Fe-rich phyllosilicates, zircon, and minor oxides and sulphides, are typical hydrothermal phases in peralkaline alkali-feldspar granites from the Corupá Pluton, Graciosa Province, South Brazil. The epidote-group minerals occur as single crystals and as aggregates filling in rock interstices and miarolitic cavities. They display complex recurrent zoning patterns with an internal zone of ferriallanite-(Ce), followed by allanite-(Ce), then epidote-ferriepidote, and an external zone with allanite-(Ce), with sharp limits, as shown in BSE and X-ray images. REE patterns show decreasing fractionation degrees of LREE over HREE from ferriallanite to epidote. The most external allanite is enriched in MREE. LA-ICP-MS data indicate that ferriallanite is enriched ( $>10$-fold) in Ti, Sr and Ga, and depleted in $\mathrm{Mg}, \mathrm{Rb}$, Th and $\mathrm{Zr}$ relative to the host granite. Allanite has lower $\mathrm{Ga}$ and $\mathrm{Mn}$ and higher $\mathrm{Zr}, \mathrm{Nb}$ and $\mathrm{U}$ contents as compared to ferriallanite, while epidote is enriched in $\mathrm{Sr}, \mathrm{U}$ and depleted in $\mathrm{Pb}, \mathrm{Zr}, \mathrm{Hf}$, Ti and Ga. The formation of these minerals is related to the variable concentrations of HFSE, $\mathrm{Ca}, \mathrm{Al}, \mathrm{Fe}$ and $\mathrm{F}$ in fluids remaining from magmatic crystallization, in an oxidizing environment, close to the HM buffer. L-MREE were in part released by the alteration of chevkinite, their main primary repository in the host rocks.
\end{abstract}

Key words: allanite, epidote, hydrothermal, compositional variations, peralkaline granite, Corupá Pluton, Graciosa Province.

\section{INTRODUCTION}

Epidote-group minerals constitute complex solid solutions series crystallized in several geological environments, making part of a variety of paragenesis in magmatic and metamorphic rocks and pegmatites, as well as hydrothermal and metassomatic rocks (Deer et al. 1986, Gieré and Sorensen 2004). The minerals in this group fit the

E-mail: srfvlach@usp.br general formula $\mathrm{A}^{(1)} \mathrm{A}^{(2)} \mathrm{M}^{(1)} \mathrm{M}^{(2)} \mathrm{M}^{(3)} \mathrm{O}\left(\mathrm{SiO}_{4} \cdot \mathrm{Si}_{2} \mathrm{O}_{7}\right)$ $(\mathrm{OH}, \mathrm{F})$, where the cations with octahedrycal and cubic or greater coordination fill in the $\mathrm{M}$ and $\mathrm{A}$ structural sites, respectively. The epidote-group mineral nomenclature, as approved by the IMA, was proposed by Armbruster et al. (2006), who recognized three main subgroups: clinozoisite, allanite, and dollaseite. Common epidote presents almost only $\mathrm{Al}^{3+}$ in $\mathrm{M}^{(1)}$ and $\mathrm{M}^{(2)}, \mathrm{Fe}^{3+}$ in $\mathrm{M}^{(3)}$, and $\mathrm{Ca}$ in $\mathrm{A}^{(1)}$ and $\mathrm{A}^{(2)}$; in clinozoisite and piemontite, 
$\mathrm{Al}^{+3}$ and $\mathrm{Mn}^{+3}$ are essential cations in $\mathrm{M}^{(3)}$, respectively. Among the REE-rich minerals in this group, the most important is allanite, where REEs substitute for $\mathrm{Ca}$ in $\mathrm{A}^{(2)}$, while $\mathrm{Fe}^{3+}$ substitutes for $\mathrm{Fe}^{2+}$ in $\mathrm{M}^{(3)}$. In the dollaseite subgroup, $\mathrm{Mg}$, $\mathrm{Fe}^{2+}$, and $\mathrm{Mn}^{2+}$ are essential cations in $\mathrm{M}^{(1)}$ and/ or $\mathrm{M}^{(3)}$. An almost complete solid solution series appears to exist between allanite and epidote endmembers. In ferriallanite (Kartashov et al. 2002) and ferriepidote, $\mathrm{Fe}^{3+}$ is the dominant cation in $\mathrm{M}^{(1)}$. Substantial reviews on the mineralogy and petrology of this group can be found in Deer et al. (1986), Gieré and Sorensen (2004) and Franz and Liebscher (2004).

Primary epidote and allanite occur as accessory phases in many granitic rocks and register important petrological information. Magmatic epidote occurs in certain relatively $\mathrm{Ca}$-rich metaluminous granitic rocks and may give important geobarometric and oxred informations (e.g. Zen and Hammarston 1984, Sial et al. 1999, Schmidt and Poli 2004). Allanite is a typical accessory mineral in metaluminous to moderately peraluminous granitic rocks and concentrates most of their LREE content. The chemical compositions of allanite correlate well with magma compositions and crystallization environments (Hoshino et al. 2006, Vlach and Gualda 2007). Epidote-group minerals are also very common as post-magmatic or meteoritichydrothermal phases in granites and related rocks, where they crystallize from late, residual and/ or external fluids incorporated from the adjacent country rocks (e.g. Exley 1980, Gieré and Sorensen 2004, Franz and Liebscher 2004, Jiang 2006, Vlach and Gualda 2007).

Relatively Ti-rich ferriallanite-(Ce) and allanite(Ce) are typical primary minerals in metaluminous to moderately peraluminous biotite sieno- and monzogranites of the aluminous (subalkaline) petrographic association from the Graciosa Province of A-type granites and syenites in S-SE Brazil (Gualda and Vlach 2007). They also occur in certain hybrid metaluminous syenites and granites from the coeval alkaline association. During the post-magmatic, hydrothermal stages, as well, allanite-(Y) and epidote were formed in slightly peraluminous granites, while ferriallanite-(Ce), allanite-(Ce) and epidote crystallized in peralkaline granites (cf. Vlach and Gualda 2007).

This work deals with micro-structural and compositional features of hydrothermal epidotegroup minerals occurring in a peralkaline alkali-feldspar granite from the Corupá Pluton, Graciosa Province, South Brazil. Optical, BSE and compositional X-ray images are integrated with quantitative chemical data for major- and traceelements obtained with EPMA and LA-ICP-MS in order to characterize their micro-structural and compositional variations and evaluate their role during post-magmatic evolution of peralkaline liquids.

The CorupÁ Pluton: General GeOlogy AND PETROGRAPHY

The Corupá Pluton (Fig. 1) is one of the most typical occurrences of the alkaline association of A-type syenites and granites from the Graciosa Province, S-SE Brazil (Y. Garin, unpublished data, Garin et al. 2003). This province was emplaced in the late Neoproterozoic (ca. $580 \mathrm{Ma}$ ) during extensional tectonic regimes (Gualda and Vlach 2007, Vlach et al. 2011). The pluton presents a crescent shape and crops out over $80 \mathrm{~km}^{2}$ in the southernmost part of the province. It is partially sided by vulcanosedimentary and sedimentary sequences from the Guaratubinha Basin and the Corupá Graben, respectively, and intrudes Archaean granulites from the Luis Alves Micro-plate. The pluton is made up mainly of syenites; granites occur as minor bodies concentrated in its internal zones, probably formed through the crystallization of residual liquids fractionated from more primitive syenitic magmas (Y. Garin, unpublished data). Coeval gabbro-diorites occur as sin-plutonic 

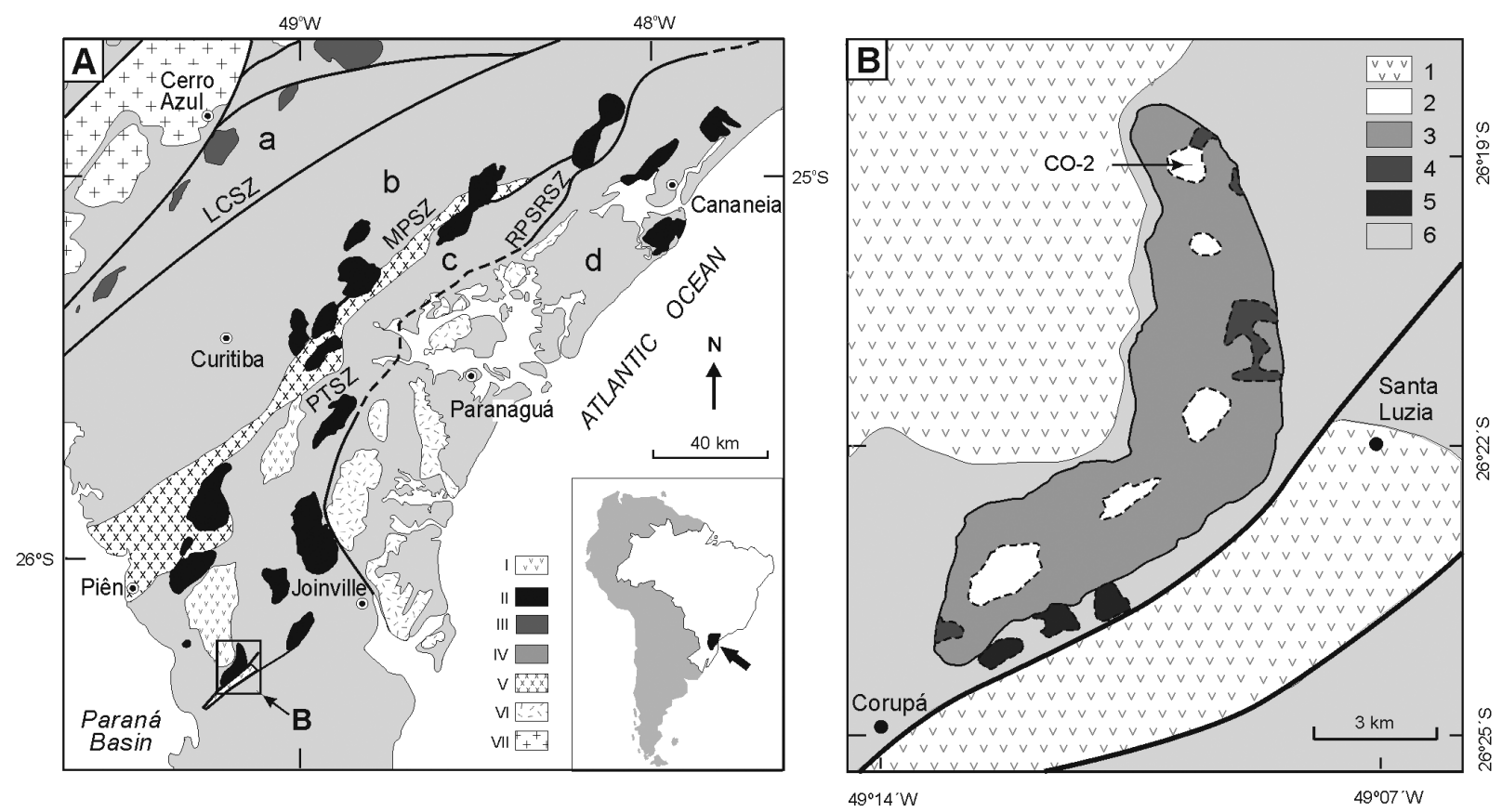

Figure 1. Simplified geologic maps of the Graciosa Province of A-type granites and syenites (A) and the Corupá Pluton (B), Southern Brazil (adapted from Y. Garin, unpublished data, Prazeres Filho et al. 2003, Gualda and Vlach 2007). (A): 1: Volcano-sedimentary basins, 2: Plutons and complexes from the A-type Graciosa Province; 3: Plutons from the A-type Itu Province (Vlach et al. 1990); IV. a: Ribeira Fold Belt, b: Curitiba Micro-plate, c: Luiz Alves Micro-plate, d: Coastal Granitoid Belt ; V: Piên-Mandirutuba Batholith; VI: Undifferentiated late- to postcollisional granites; VII: Três Córregos Batholith. LCSZ: Lancinha Shear Zone; RPSRSZ: Rio Palmital-Serrinha Shear Zone. (B): 1: Sedimentary and volcanic rocks from Guaratubinha Basin (above) and Corupá Graben (below); 2: Alkali-feldspar granites, 3: Undifferentiated alkali-feldspar syenites, 4: Gabbro-diorites and related hybrid rocks, 5: Basic volcanics, 6: Archaean granulitic rocks from the Luis Alves Micro-plate. CO-2 sample location as indicated.

minor bodies, while hybrid monzodiorites and monzosyenites appear as rounded enclaves with variable dimensions within some medium-grained syenite varieties (Garin et al. 2003).

The syenitic rocks comprise green to pink colored, medium- to coarse-grained, alkali-feldspar syenites and quartz syenites (Y. Garin, unpublished data, Vlach and Gualda 2007). Structures are massive to slightly oriented by magmatic flow, and textures are inequigranular hypidiomorphic, with well-developed K-feldspar tabular crystals. They are metaluminous rocks showing mainly mesophertitic alkali feldspar, with variable amounts of mafic minerals $(20<\mathrm{M}<7)$ and quartz $(<10$ vol. \%). The more mafic syenites contain fayalite, diopside-hedenbergite and calcic amphibole as primary phases. Hedenbergite, calcic and sodic- calcic amphiboles are observed in more evolved varieties. Medium- to coarse-grained alkali-feldspar melasyenites ( $\mathrm{M}$ up to 65 ) occur as cumulatic rocks interlayered with the coarse grained syenites in stratified units with restricted distribution. Accessory minerals include mainly ilmenite, chevkinite, zircon and rare apatite; Ti-magnetite occur in some of the most primitive (quartz-absent) syenites, while late titanite is occasional in some evolved syenites. Most of the evolved syenites contain variable amounts of Al-poor, Fe-rich biotite and chlorite, stilpnomelane, actinolitic amphibole, albite and quartz as postmagmatic, hydrothermal minerals, filling in interstices among the main phases.

The alkali-feldspar granites are mediumgrained homogeneous and slightly pink colored rocks with massive structure. Textures are egui- 
granular hypidiomorphic. They are leucocratic to hololeucocratic rocks $(6<M<4)$, with a peralkaline signature $(1.03<\mathrm{A} / \mathrm{NK}<1.06)$ made of mesophertitic alkali feldspar, quartz and interstitial sodic amphibole (riebeckite), sometimes with sodiccalcic cores, as the main mafic phase. Graphic intergrowths of alkali-feldspar and quartz are common features. Ilmenite, chevkinite, zircon, late titanite and some sphalerite are the main primary accessories. The post-magmatic mineral assemblage will be discussed in the following sections.

\section{MATERIALS AND METHODS}

Several samples of the Corupá peralkaline granites were studied in polished thin sections and the features described in this paper are common to most of them. Sample CO-2 (Fig. 1) was selected for a detailed analytical work because it is very fresh, the described micro-structural features are better developed and an almost complete whole-rock and mineral geochemical data set is available for.

Images of hydrothermal epidote-group minerals and quantitative analysis were obtained at the Optical, EPMA and LA-ICP-MS laboratories at Departamento de Mineralogia e Geotectônica, Instituto de Geociências, Universidade de São Paulo.

The EPMA laboratory has a JEOL-JXA8600S equipment with 5 wavelength and 1 dispersive spectrometers automated with the Thermo-Noran Voyager 4.3 system. Qualitative and quantitative analyses were made on $\mathrm{C}$-coated polished thin sections, 30 and $80 \mu \mathrm{m}$ thick. BSE-Compo imaging and combined WDS and EDS X-ray dot mapping were used to monitor micro-structural and compositional variations. Dot maps were obtained in selected areas, under $20 \mathrm{kV}$ and 100 $\mathrm{nA}$ for the column acceleration voltage and beam current, with a resolution of 512 vs. 512 pixels and a dwell time of $0.1 \mathrm{~s}$. Mapped elements were: Si $\mathrm{K} \alpha$ and $\mathrm{Fe} \mathrm{K} \alpha(\mathrm{EDS}), \mathrm{Al} \mathrm{K} \alpha, \mathrm{Ce} \mathrm{L} \alpha, \mathrm{CaK} \alpha$, Ti K $\alpha$ and $\mathrm{SrL} \alpha(\mathrm{WDS})$. Si and Fe regions of interest were selected with the minimum possible width.

Quantitative WDS point analyses were made under $20 \mathrm{kV}, 50 \mathrm{nA}$ and 1-2 $\mu \mathrm{m}$ for the column acceleration voltage, beam current and diameter, respectively, following the procedures described by Vlach and Gualda (2007). Matrix effects were corrected with the PROZA procedure (e.g. Bastin and Heijligers 1990). Estimated precision was better than $2 \%$ for major, between 5 and $10 \%$ for minor, and worse for trace elements.

Over 60 point analyses were obtained for the epidote-group minerals. The $\mathrm{Fe}^{2+} / \mathrm{Fe}^{3+}$ partition was calculated with the MinCal program (G.A.R. Gualda and S.R.F. Vlach, unpublished data) based on 8 total cations and 25 negative charges, according to Droop (1987). The studied minerals show significant chemical variations in the epidoteallanite-ferriepidote-ferriallanite system. They are very pristine and clear, as the radiation dose was not high enough to cause significant damage, given the low $\mathrm{Th}(<50 \mathrm{ppm})$ and $\mathrm{U}(<10 \mathrm{ppm})$ contents. So, $\mathrm{Fe}^{2+} / \mathrm{Fe}^{3+}$ were also computed following other methods discussed in the literature and results were compared. Structural formulae were calculated according to the suggestions of Dollase (1971), Ercit (2002), Franz and Liebscher (2004) and Armbruster et al. (2006).

LA-ICP-MS analyses were made both in spot (allanite) and raster (epidote) modes in $80-\mu \mathrm{m}$ thick polished thin sections using the Elan 6100DRC ICP-MS equipped with a New Wave UP-213 LA system, with a $213 \mathrm{~nm} \mathrm{Y(Nd)AlG} \mathrm{laser.} \mathrm{The} \mathrm{energy}$ density and the beam diameter at the sample surface were close to $8.6 \mathrm{~J} / \mathrm{cm}^{2}$ and 65 (spot) or 40 (raster) $\mu \mathrm{m}$, respectively. The used analytical protocol was similar to that presented by Gao et al. (2002), and 44 elements were quantified with a total acquisition time of 120 s, equally divided for sample and blank measurements. Signal integration and dwell times were 8.3 and $1.66 \mathrm{~ms}$, respectively. Daily oxide formation ratio was controlled by $\mathrm{ThO}$ formation 
ratio and maintained below $1 \%$. Data acquisition, drift corrections, as well as data treatment and conversions to concentrations were done with the Glitter software (van Achterbergh et al. 2007). Synthetic glasses SRM-612 (NIST) and BHVO$2 \mathrm{G}$ were used as standards. Si and $\mathrm{Ca}$ contents, previously measured with EPMA, were used as internal standards for normalization purposes.

The spatial resolution of the LA-ICP-MS technique, about 4 to 5 orders of magnitude lower than EPMA, turns difficult to solve the thinnest compositional variations in the analyzed crystals and aggregates. The presented spot and raster analyses were obtained in the most homogeneous volumes found after high resolution optical and BSE imaging.

\section{RESULTS}

\section{MicRO-STRUCTURAL FEATURES}

In the studied samples, hydrothermal epidote-group minerals occur as isolated idiomorphic crystals and as aggregates of smaller prismatic to acicular grains, sometimes arranged in a radiated form. Most of them present submilimetric dimensions and fill in interstices between the primary minerals as well as miarolitic cavities in the granite. They constitute $<0.1$ vol. \% of the CO-2 sample and are mainly associated with clear albite (An $<2$ mol. \%), quartz, dark green $\mathrm{Al}$-poor and $\mathrm{Fe}$-rich biotite and chlorite, fluorite, zircon, and occasionally some magnetite, hematite and galena as minute opaque crystals.

The most typical micro-structures of the epidote-group minerals in the studied granite are exemplified in Fig. 2, which depicts plane polarized optical, BSE, as well as $\mathrm{Ca}, \mathrm{Al}, \mathrm{Fe}, \mathrm{Ce}$, $\mathrm{Ti}$, and Sr X-ray images for a single crystal and/or a crystalline aggregate. In both cases, well marked complex oscillatory zoning patterns are observed. In general, four main compositional zones, with abrupt mutual contacts, may be recognized from core to rims: the most internal zone (I) displays higher light absorption with red to dark brown (Z) and dark red to brown (X) pleochroic colors, higher backscattered coefficients and relatively higher $\mathrm{Fe}, \mathrm{Ce}$, and $\mathrm{Ti}$, and lower $\mathrm{Al}$ and $\mathrm{Ca}$ contents; the next zone (II) shows lighter colors, as is typical in common allanite, lower backscattered coefficients, and lower $\mathrm{Fe}, \mathrm{Ce}$ and $\mathrm{Ti}$, and higher $\mathrm{Al}$ and $\mathrm{Ca}$ contents. Along the fast growing direction of the crystals, which corresponds to the b crystallographic axis, zone I presents a typical swallow-tailed contact against zone II.

The third zone (III) is more transparent and clear with orange to yellow and green pleochroic colors, as in a typical epidote, with higher X-ray intensities for $\mathrm{Ca}$ and, to a lesser extent, $\mathrm{Al}$, and lower for Ce and Ti. The last external zone (IV) is constituted by allanite with similar properties of zone II. Sr concentrates mainly in the epidote zone, particularly in epidote filling in interstices between crystal-forming aggregates, and correlates directly with $\mathrm{Al}$ and inversely with Fe. In general, zones I and II are more homogeneous, while thin zoning patterns identified by $\mathrm{Ca}, \mathrm{Al}, \mathrm{Ce}$ and/or $\mathrm{Ti}$ intensity changes appear in the epidote and the external allanite zones (III and IV, respectively) in both isolated crystals and crystal aggregates. A thin allanite zone with higher intensities of $\mathrm{Ce}$ and Ti, precipitated immediately over the epidote zone III, is a common feature in the internal part of the allanite zone IV. In the most external epidote and allanite zones, crystals in the aggregates lost their chemical individuality in the images.

In some cases (not shown) isolated crystals are devoid of zones III and IV, and some aggregates do not present zone I. Rare crystal aggregates appear to be constituted only by allanite with properties similar to the ones described for zone IV. In other cases, the allanite from zone I appears to be constituted of several acicular crystals immersed in allanite from zone II, which seem to diverge from a 

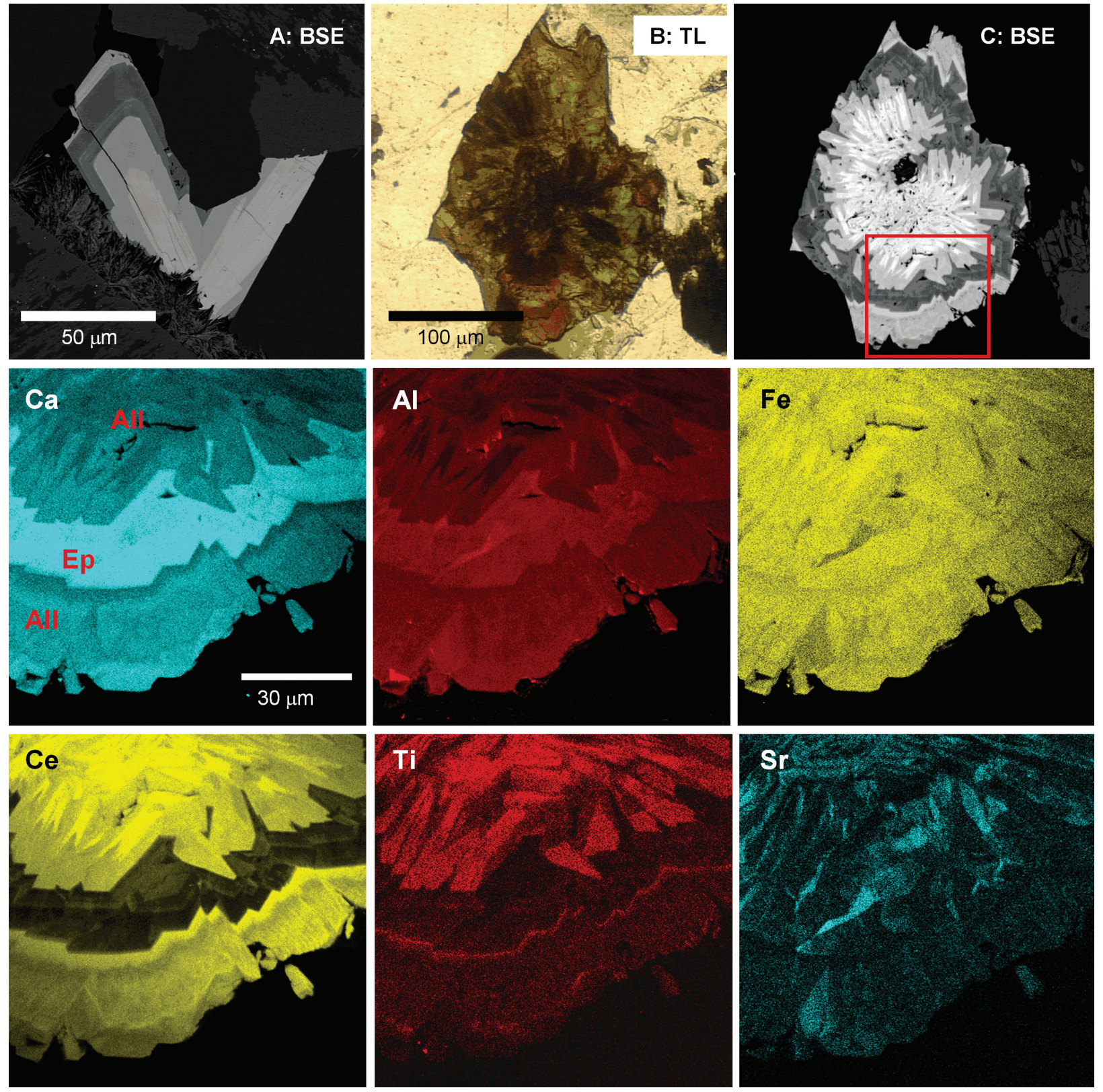

Figure 2. Representative images for the hydrothermal epidote-group minerals from the Corupá alkali-feldspar granite, sample CO-2. A: BSE image of a single zoned crystal [reproduced from Vlach and Gualda (2007) with Elsevier permission]; clear zones are ferriallanite (clearest) and allanite; relatively darker zones correspond to epidote and ferri-epidote; B: transmitted plane polarized image for a typical epidote-group crystal aggregate; C: BSE image of the aggregate shown in B. A and B images depict better the main compositional zones as discussed in the text. Others: X-ray dot compositional maps showing the distribution of the indicated elements in the crystalline aggregate area drawn in C. See text for discussion.

common growing substrate, as illustrated in Fig. 2. The zones with the highest transparency, as epidote and allanite zones II, III, and IV, are always very pristine, with birefringence between 0.3 and 0.4 , and do not show radioactive damage evidence.

\section{Chemical Compositions}

Representative WDS analyses and structural formulae for epidote-group minerals from sample CO-2 are presented in Table I. The whole data set is 


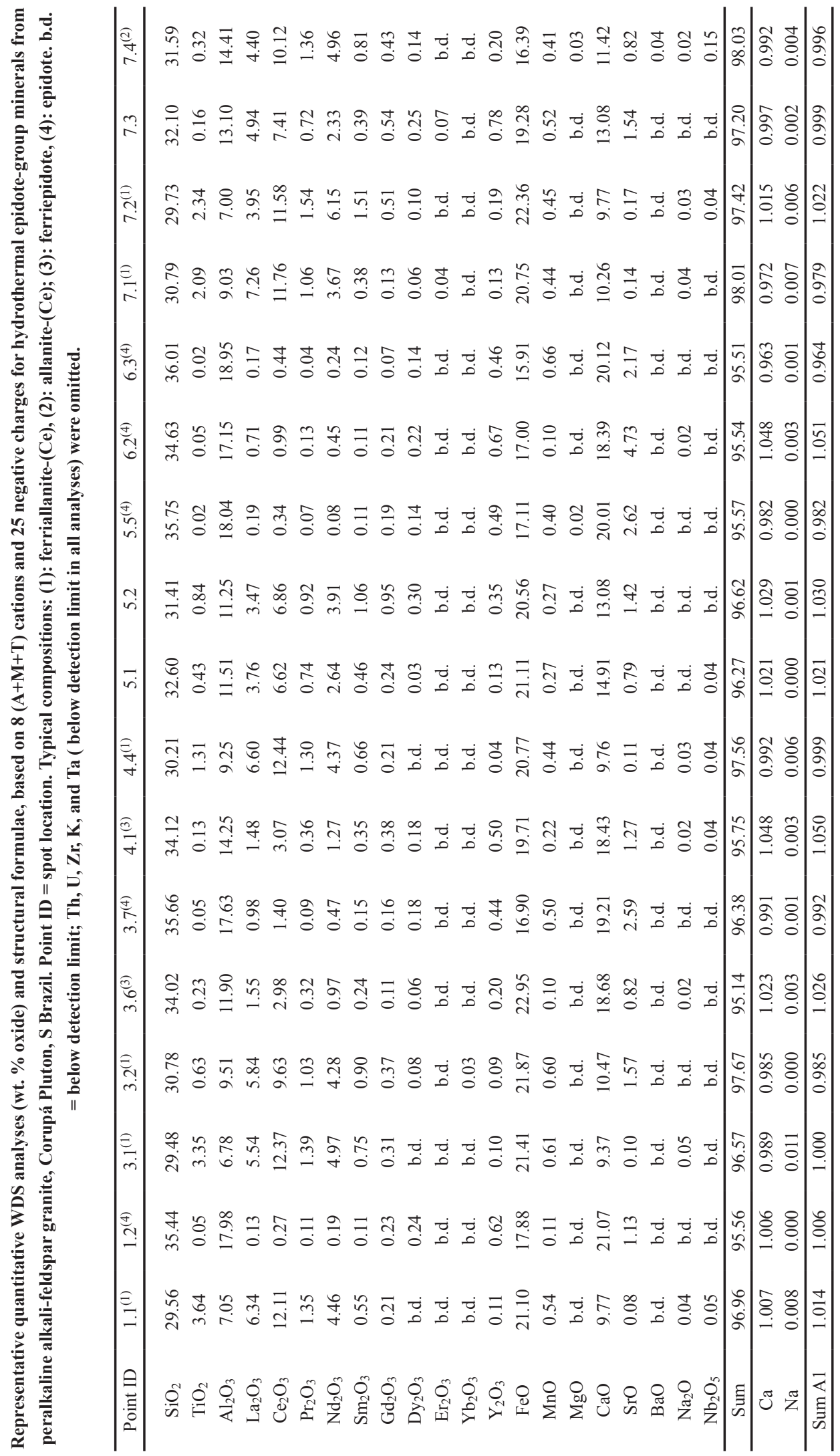




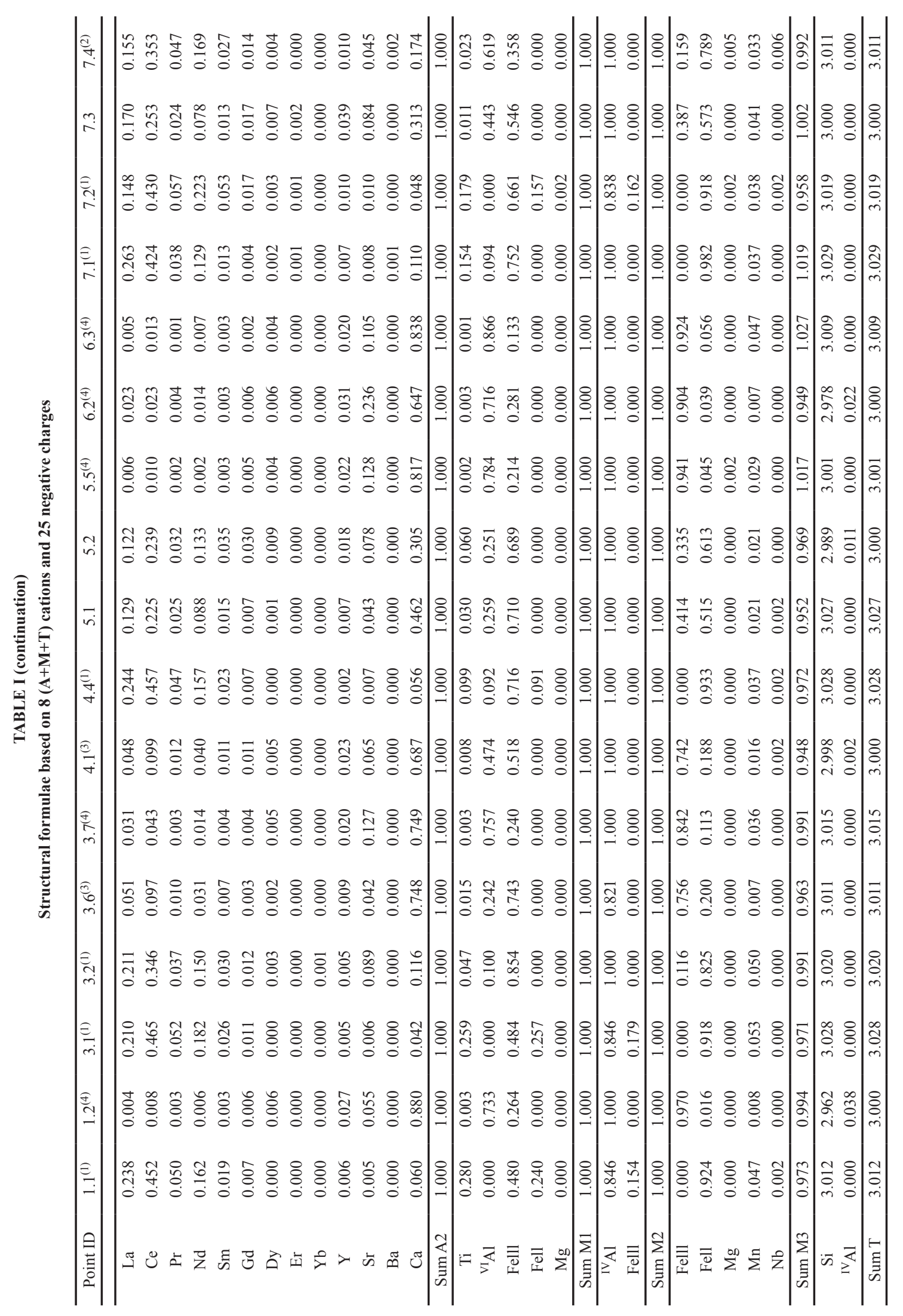


available by request to the author. LA-ICP-MS data for lanthanide and trace elements are presented in Table II. The hydrothermal epidote-group minerals are ferriallanite-(Ce) and allanite-(Ce), ferriepidote and epidote (cf. Table I) and belong to the allanite and clinozoisite subgroups of Armbruster et al. (2006). Most epidote compositions have appreciable $\mathrm{Sr}$ contents, up to 0.236 a.p.f.u.

\section{Main features}

The main chemical characteristics of the Corupá epidote-group minerals are well described by the compositional variations of the single zoned crystal shown in Fig. 2A, as depicted in Fig. 3. This figure nicely illustrates the main chemical variations obtained closely along the b crystallographic axis, expressed in oxide wt. \% of major and minor elements, as well as $\mathrm{Fe}^{3+} /\left(\mathrm{Fe}^{3+}+\mathrm{Fe}^{2+}\right)$ ratios, and their correlations with zones I, II, III, and IV, as discussed in the following.

The chemical compositions here presented appear to cover almost all the range between the epidote and allanite end members. Fig. 4 shows the cationic proportions of $(\mathrm{REE}+\mathrm{Y})$ in the A site as plotted against the ${ }^{\mathrm{VI}} \mathrm{M}^{2+}$ cations in the $\mathrm{M}$ site. The compositional distributions along the epidoteallanite join in this diagram has been used as an evidence of extensive solid solution between these end members. Our results present a very good correlation (determination coefficient $r^{2}=0.94$ ) and show, in relation to the ideal allanite end-member, a shift towards a relative excess of the VIM2+ cations in M-sites, a feature shared by most available data in the literature, for which the $\mathrm{Fe}^{3+} / \mathrm{Fe}^{2+}$ partition was estimated (e.g. Gieré and Sorensen 2004).

The cationic substitution schemes in the epidote-group minerals were revised by Gieré and Sorensen (2004), Franz and Liebscher (2004) and Armbruster et al. (2006). The entry of the rare-earth elements in the (REE+Y)-bearing members involves exchange with $\mathrm{Ca}$ (and $\mathrm{Sr}$ ),

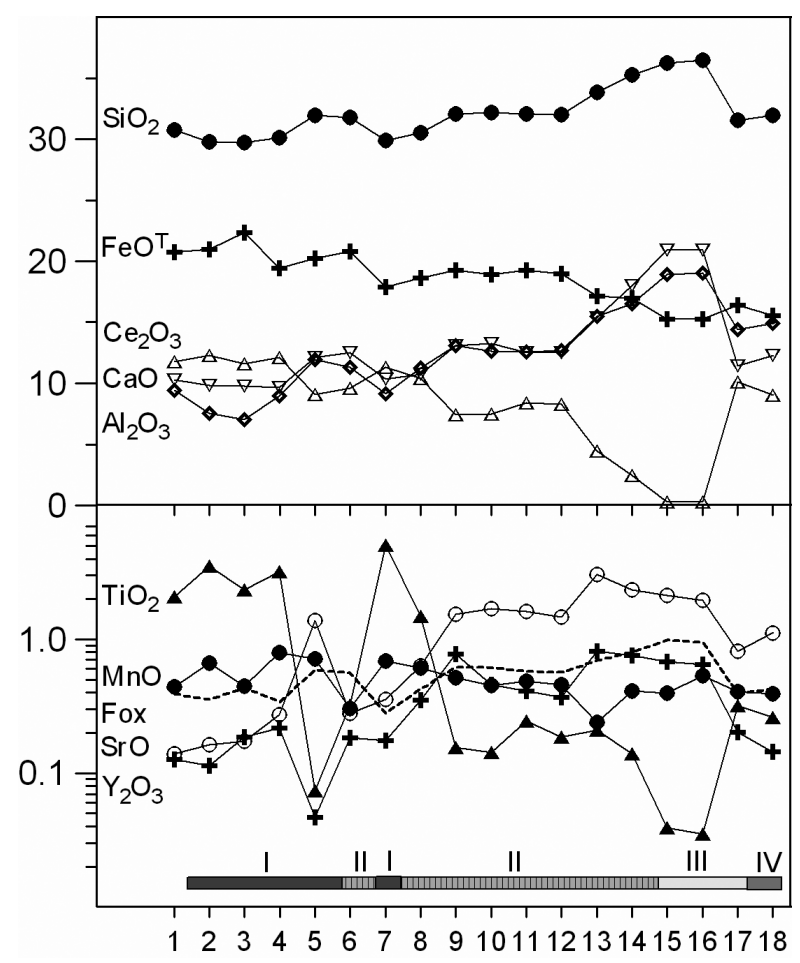

Figure 3. Compositional section closely along the b crystallographic axis showing the main variations for the single crystal displayed in Fig. 2A. Note the logarithmic scale of the lower diagram. Heavy dotted line: Fox $\left[=\right.$ estimated $\left.\mathrm{Fe}^{3+} /\left(\mathrm{Fe}^{3+}+\mathrm{Fe}^{2+}\right)\right]$. Bar indicates compositional zones I (heavy gray), II (dashed gray), III (light gray) and IV (medium gray) as defined in the text. Bar and spot locations were chosen in order to quantitatively represent all the contrasted compositional zones as identified in light and/or BSE images and were not scaled or equally spaced. Comments in the text.

as described by the $\left[\mathrm{REE}^{3+} \mathrm{Fe}^{2+}\right]\left[\mathrm{CaAl}^{3+}\right]_{-1}$ and $\left[\mathrm{REE}^{3+} \mathrm{Fe}^{2+}\right]\left[\mathrm{CaFe}^{3+}\right]_{-1}$ main vectors. The relation between the cationic proportions of $\mathrm{Ca}+\mathrm{Sr}$ and REE $+Y$ (almost equal 1:1, cf. Fig. 5), with an exceptional $r^{2}=1$, demonstrated that at least one of these exchange vectors plays a major role in the observed compositional variations. The obtained compositions are distributed along the entire epidote-allanite range (cf. Fig. 4), but a few ones plot in the intermediate zone of this diagram, with $\mathrm{REE}+\mathrm{Y}$ values between 0.3 and 0.6 a.p.f.u.

Compositional variations in the clinozoisiteepidote-allanite-ferriallanite are well depicted in the $\mathrm{REE}+\mathrm{Y}+\mathrm{Th}+\mathrm{Sr}$ (A site occupancy excluding Ca) vs $\mathrm{Al}^{\mathrm{T}}$ diagram (Petríck et al. 1995), which also 
allows to estimate the $\mathrm{Fe}^{3+} /\left(\mathrm{Fe}^{3+}+\mathrm{Fe}^{+}\right)$ratios, as discussed in the next section. An expanded version, to include the end-member ferriepidote, of this diagram is shown in Fig. 6. Most of the Corupá analyses plot in the quadrangular epidote-allaniteferriepidote-ferriallanite area; exceptions are some analyses with REE $+\mathrm{Y}+\mathrm{Th}+\mathrm{Sr}$ greater than 1 a.p.f.u. and others with deficient $\mathrm{Al}$ in the $\mathrm{M}^{(2)}$ sites, or both. Such Al deficiency points to Fe occupancies in the $\mathrm{M}^{(2)}$ sites up to 0.18 a.p.f.u. (see Table I).

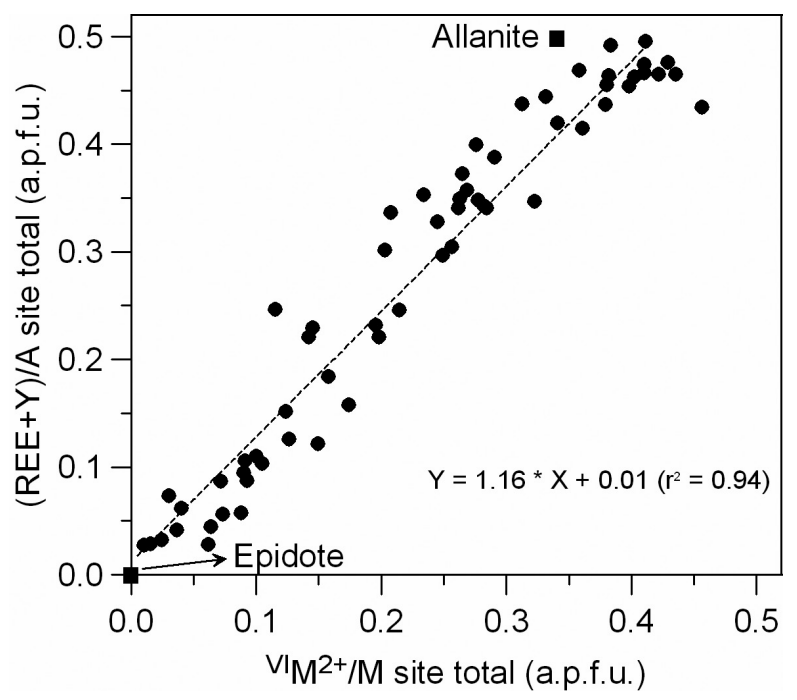

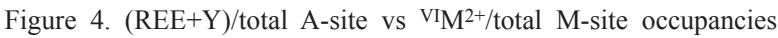
(after Gieré and Sorensen 2004) for the hydrothermal epidote-group minerals from the Corupá alkali-feldspar granite. Full squares indicate ideal compositions of epidote and allanite end-members. Note the good data correlation and compositional shift towards the right side of the epidote-allanite join.

The distribution of the analytical points in the diagram suggests again that there is not a continuous trend, neither along $\left[\mathrm{REE}^{3+} \mathrm{Fe}^{2+}\right]\left[\mathrm{CaFe}^{3+}\right]_{-1}$, nor along $\left[\mathrm{REE}^{3+} \mathrm{Fe}^{2+}\right]\left[\mathrm{CaAl}^{3+}\right]_{-1}$, exchange vectors, as there are few compositions in the $0.4<$ $(\mathrm{REE}+\mathrm{Y}+\mathrm{Th}+\mathrm{Sr})<0.6$ a.p.f.u. interval. In general, allanite compositions close to the ferriallanite end-member represent allanite from zone I, while others are mainly from zone II. The allanite zone IV is relatively more Al-rich, and (REE+Y)-poor and their compositions are somewhat displaced

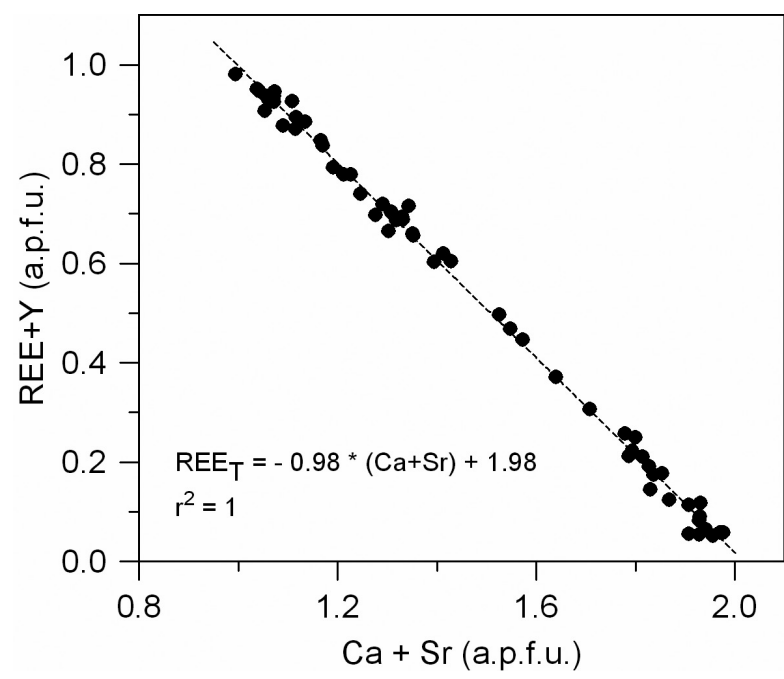

Figure 5. $\mathrm{RRE}+\mathrm{Y}$ vs. $\mathrm{Ca}+\mathrm{Sr}$ plot for the hydrothermal epidote-group minerals from the Corupá alkali-feldspar granite. Note few analytical points in the range $0.3<\mathrm{REE}+\mathrm{Y}<0.6$ and the exceptional data correlation. Comments in the text.

towards the allanite-epidote join. Among the epidote compositions, those displaced towards the ferriepidote end-member are more representative of the crystal aggregates, while compositions that plot close to the epidote-ferriallanite join were obtained almost only in single crystals.

The compositions of hydrothermal epidotegroup minerals from two other granite occurrences are plotted in this diagram for comparison purposes: allanite-(Y) from the Capivari Pluton of the Graciosa Province (Vlach and Gualda 2007) and epidote and allanite from the Skye Igneous Complex, Scotland (Exley 1980). The compositions of the latter define a significant compositional range as well, parallel to the $\left[\mathrm{REE}^{3+} \mathrm{Fe}^{2+}\right]\left[\mathrm{CaFe}^{3+}\right]_{-1}$ exchange vector. As a whole, the Skye compositions are richer in $\mathrm{Al}^{\mathrm{T}}$ and their plots are displaced to the right of the diagram: compositions close to the ferriallanite and ferriepidote end-members are lacking, while some analyses yet contain a small contribution of the clinozoisite endmember. This correlates with the relatively more aluminous character of the host granites, in contrast with the marked peralkaline signature of the Corupá sample. The Y-richest analyses from Skye are 


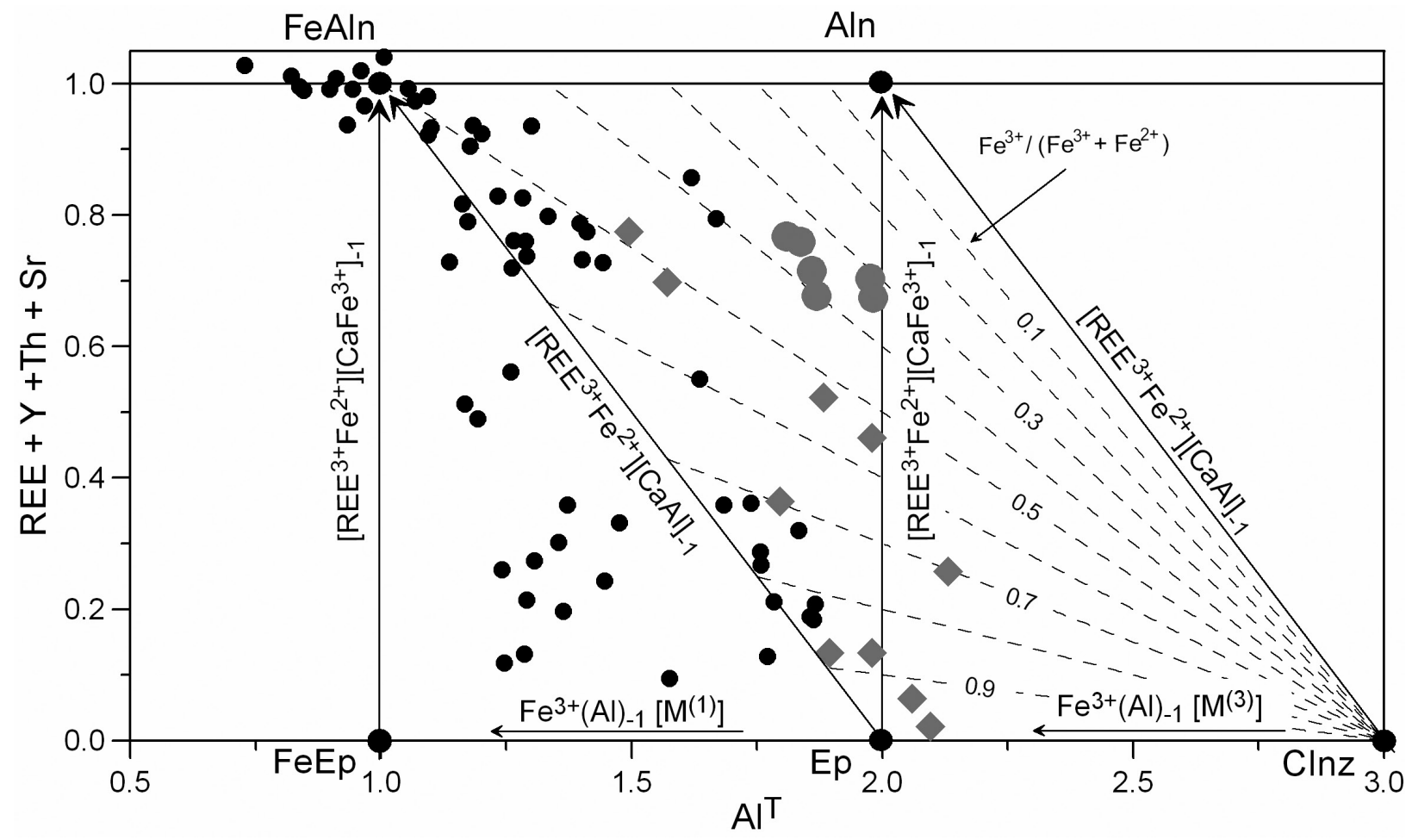

Figure 6. Total A-site occupancy, excluding Ca, vs. $\mathrm{Al}^{\mathrm{T}}$ diagram, as modified from Petríck et al. (1995) to incorporate the ferriepidote molecule. FeAln = ferriallanite, $\mathrm{Aln}=$ allanite, $\mathrm{FeEp}=$ ferriepidote, $\mathrm{Ep}=$ epidote, $\mathrm{Clnz}=$ clinozoisite. Full heavy circles: Corupá peralkaline alkali-feldspar granite; full light circles: aluminous biotite granite from the Capivari Pluton, Graciosa Province (Vlach and Gualda 2007); full light diamonds: biotite granites from the Skye Igneous Complex (Exley 1980). Note the reduced number of compositions in the intermediate zone between epidoteferriepidote and allanite-ferriallanite. See text for discussion.

similar to the allanite-(Y) from the Capivari Pluton, composed by biotite granites from the aluminous association of the province.

$$
\mathrm{Fe}^{3+} /\left(\mathrm{Fe}^{3+}+\mathrm{Fe}^{2+}\right) \text { ratios }
$$

It is difficult to estimate $\mathrm{Fe}^{3+} /\left(\mathrm{Fe}^{3+}+\mathrm{Fe}^{2+}\right)$ ratios (Fox) from EPMA analyses, specially for the REE, Th and $U$ relatively rich end-members of the epidote-group minerals. This is due to the possible presence of vacancies in the A-sites, of trivalent $\mathrm{Mn}$, site-occupancy uncertainties, as well as chemical exchanges launched by hydrothermal alteration (Wood and Ricketts 2000, Poitrasson 2002) and structural damage caused by Th and $U$ radioactive decays.

The best estimation methods, according to Ercit (2002), are based on $6(\mathrm{M}+\mathrm{T})$ or $8(\mathrm{~A}+\mathrm{M}+\mathrm{T})$ cations and 25 negative charges, the first being superior as it does not depend on A-site vacancies. However, the second method was indicated by the IMA, taking into account the data obtained by Bonazzi et al. (1996), which seems to indicate some $\mathrm{Mn}^{2+}$ and, to a lesser extent, $\mathrm{Fe}^{2+}$ filling in $\mathrm{M}^{(1)}, \mathrm{M}^{(3)}$ and $\mathrm{A}^{(1)}$ sites (cf. Armsbruster et al. 2006, Franz and Liescher 2004, Gieré and Sorensen 2004). It was nevertheless emphasized that this method does not work well when there are A-site vacancies and/or if the analyses are not complete. Fox ratios should also be estimated from $(\mathrm{REE}+\mathrm{Y}+\mathrm{Th}+\mathrm{Sr})$ and $\mathrm{Al}^{\mathrm{T}}$ relations in the subsystem clinozoisite-epidote-allanite-ferriallanite (cf. Fig. 6), as graphically depicted in Petríck et al. (1995) and algebraically wrote by Poitrasson (2002). The first authors showed that the obtained results were 
in well agreement with independent Mössbauer determinations. This method may be applied to overcome minor problems related to analytical errors on $\mathrm{Si}$ and $\mathrm{Fe}$ and incomplete analyses, as well as to some late chemical transformations not affecting the involved elements. There are cases, however, in which minerals in this subsystem contain substantial Ti amounts, a feature typical of allanite and ferriallanite from A-type granites and related rocks, and the results will be overestimated (Vlach and Gualda 2007).

A graphical comparison of the Fox ratios estimated with these methods for the obtained data is presented in Fig. 7. The ratios computed on the basis of $6(\mathrm{M}+\mathrm{T})$ and $8(\mathrm{~A}+\mathrm{M}+\mathrm{T})$ cations are equivalent within the whole compositional range and, thus, incompatible with the presence of significant $\mathrm{Fe}^{2+}$ or $\mathrm{Mn}^{2+}$ contents, as well as vacancies, in the A site. The correlation between them and the ratios computed according Petríck et al. (1995) is always poor, as the epidote-ferriepidote compositions, related by the $\left[\mathrm{Fe}^{3+}\right][\mathrm{Al}]_{-1}$ exchange vector, are outside the considered subsystem and our allanite-ferriallanite compositions present variable but significant $\mathrm{Ti}$ contents, incorporated through the coupled $\left[\mathrm{Ti}^{4+}+\mathrm{Fe}^{2+}\right]\left[\mathrm{Al}^{3+}\right]_{-2}$ exchange vector (Vlach and Gualda 2007).

The available data plotted in Fig. 8 were used to devise a correction for the Ti effect on the Fox estimates obtained by the method of Petríck et al. (1995), which may be written as follows:

$$
\text { Fox }_{\mathrm{C}} \cong \text { Fox }_{\mathrm{P}}-(0.88 * \mathrm{Ti} \text { (a.p.f.u.) }-0.03) \quad\left[\mathrm{r}^{2}=0.81\right]
$$

where Fox $x_{\mathrm{C}}$ is the corrected and Fox is the Petríck et al. ratio, respectively.

\section{REE AND TRACE ELEMENTS PATTERNS}

The REE + Y contents in the hydrothermal Corupá ferriallanite-(Ce) amount to up 1.05 a.p.f.u. (26.6 wt.\%), while the equivalent contents in epidote-ferriepidote

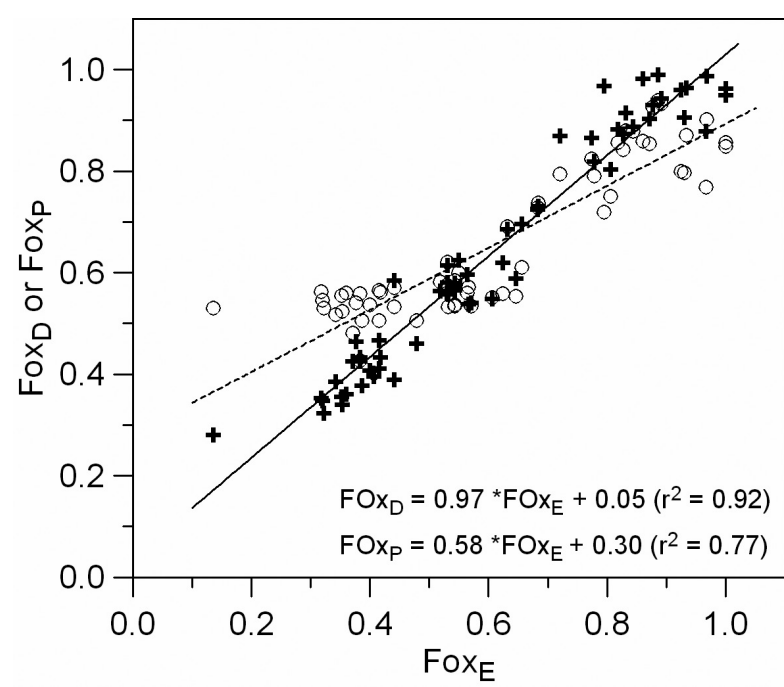

Figure 7. Comparison of the estimated Fox ratios $\left[=\mathrm{Fe}^{3+} /\left(\mathrm{Fe}^{3+}\right.\right.$ $\left.+\mathrm{Fe}^{2+}\right)$ ] for the epidote-group minerals from the Corupá alkalifeldspar granite as computed with different methods. $F o x_{\mathrm{D}}$ (crosses): $8(\mathrm{~A}+\mathrm{M}+\mathrm{T})$ cations and 25 negative charges; Fox $_{\mathrm{P}}$ (open circles): graphical method of Petríck et al. (1995); Fox $x_{\mathrm{E}}: 6(\mathrm{M}+\mathrm{T})$ cations and 25 negative charges (Ercit 2002). Note the excellent linear correlation with angular coefficient close to unity between $F o x_{\mathrm{D}}$ and $F o x_{\mathrm{E}}$ values.

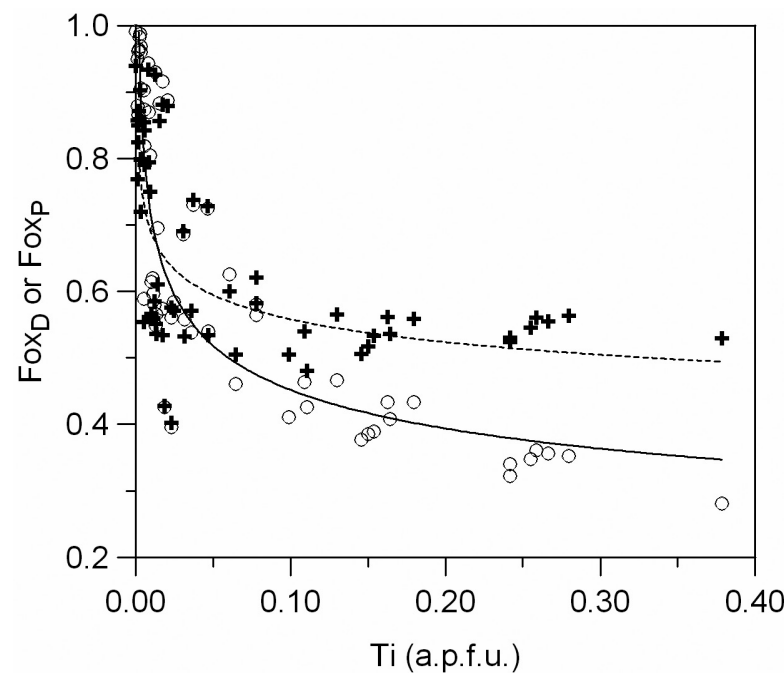

Figure 8. Diagram illustrating the deviations of the Fox ratios calculated with the Petríck et al. (1995) method (crosses) towards higher values in relation to the ratios obtained with $8(\mathrm{~A}+\mathrm{M}+\mathrm{T})$ cations and 25 negative charges (open circles) as a function of the Ti content in ferriallanite and allanite from the Corupá alkali-feldspar granite.

compositions are as low as 0.05 a.p.f.u. (1.4 wt. \% oxide, cf. Table I). Representative normalized REE patterns obtained with EPMA and LA-ICP-MS for 
TABLE II

Quantitative LA-ICP-MS data (ppm) for hydrothermal epidote-group minerals from peralkaline alkali-feldspar granite, Corupá Pluton, S Brazil. Point ID: spot/raster location, $2 \mathrm{~s}=$ estimated standard deviation (given in absolute values, $95 \%$ confidence level). b. d. = below detection limit. Cs, Co, Ni, Mo and Sb values (close to or below detection limits in all analyses) were omitted. (1): ferriallanite-(Ce), (2): allanite-(Ce), (3): epidote.

\begin{tabular}{|c|c|c|c|c|c|c|c|c|c|c|c|c|c|c|c|c|c|c|}
\hline $\begin{array}{c}\text { Point } \\
\text { ID }\end{array}$ & c1p1 $1^{(1)}$ & $2 s$ & $\operatorname{c1p} 2^{(1)}$ & $2 s$ & c1p3 & $2 s$ & c2p3 $3^{(2)}$ & $2 \mathrm{~s} \mathrm{w}$ & c2p4 & $2 s$ & c2p5 $5^{(1)}$ & $2 s$ & c2p6 & $2 s$ & c3p1 & $2 s$ & c4p1 $1^{(3)}$ & $2 s$ \\
\hline $\mathrm{Li}$ & 1.7 & 0.4 & 8.1 & 0.9 & 1.6 & 0.3 & 16.3 & 1.7 & 3.1 & 0.6 & 3.8 & 0.6 & 2.0 & 0.4 & b.d. & - & b.d. & - \\
\hline $\mathrm{Be}$ & 2.0 & 1.0 & 1.3 & 0.7 & 0.4 & 0.4 & 1.4 & 0.9 & 1.6 & 1.0 & 1.0 & 0.7 & 0.8 & 0.7 & b.d. & - & b.d. & - \\
\hline $\mathrm{Mg}$ & 13.3 & 1.5 & 21.4 & 2.1 & 12.0 & 1.4 & 32.3 & 3.0 & 21.3 & 2.3 & 17.0 & 1.9 & 12.7 & 1.5 & 288 & 33 & b.d. & - \\
\hline $\mathrm{P}$ & 53 & 6 & 75 & 7 & 57 & 6 & 38 & 5 & 62 & 7 & 62 & 7 & 68 & 7 & b.d. & - & b.d. & - \\
\hline $\mathrm{Sc}$ & 2.5 & 0.3 & 2.2 & 0.2 & 1.6 & 0.2 & 6.5 & 0.5 & 3.3 & 0.3 & 2.1 & 0.2 & 1.8 & 0.2 & 1.0 & 0.2 & 5.7 & 1.1 \\
\hline $\mathrm{Ti}$ & 7848 & 572 & 97773 & 729 & 6165 & 467 & 906 & 74 & 6967 & 572 & 8215 & 707 & 5290 & 468 & 199 & 25 & 1828 & 168 \\
\hline $\mathrm{V}$ & 0.9 & 0.1 & 0.7 & 0.1 & 0.9 & 0.1 & 0.5 & 0.1 & 1.2 & 0.2 & 1.2 & 0.1 & 1.2 & 0.1 & 0.58 & 0.14 & 1.7 & 0.5 \\
\hline $\mathrm{Cr}$ & 2.4 & 0.8 & 3.6 & 0.8 & 2.3 & 0.8 & 2.7 & 0.9 & 2.4 & 1.0 & 3.6 & 0.9 & 2.2 & 0.8 & b.d. & - & 33.3 & 9.9 \\
\hline $\mathrm{Mn}$ & 2338 & 156 & 3012 & 203 & 2470 & 168 & 1524 & 108 & 2815 & 202 & 2969 & 219 & 2697 & 203 & 4572 & 566 & 1047 & 74 \\
\hline $\mathrm{Cu}$ & 0.9 & 0.2 & 1.2 & 0.2 & 0.5 & 0.2 & 0.2 & 0.1 & 0.7 & 0.2 & 0.7 & 0.2 & 0.4 & 0.2 & 0.4 & 0.2 & b.d. & - \\
\hline $\mathrm{Zn}$ & 130 & 9 & 180 & 12 & 128 & 9 & 140 & 10 & 153 & 11 & 146 & 11 & 129 & 10 & 15.0 & 1.1 & 32.3 & 5.5 \\
\hline $\mathrm{Ga}$ & 897 & 58 & 982 & 64 & 855 & 56 & 479 & 32 & 1013 & 69 & 1126 & 79 & 950 & 67 & 159 & 18 & 369 & 29 \\
\hline $\mathrm{Rb}$ & 1.3 & 0.1 & 3.0 & 0.3 & 0.5 & 0.1 & 0.8 & 0.1 & 0.5 & 0.1 & 0.2 & 0.0 & 0.4 & 0.1 & 1.0 & 0.1 & 0.3 & 0.2 \\
\hline $\mathrm{Sr}$ & 5548 & 445 & 3085 & 255 & 6064 & 513 & 5935 & 543 & 7253 & 683 & 2857 & 287 & 6880 & 714 & 18711 & 1630 & 5171 & 432 \\
\hline $\mathrm{Y}$ & 1525 & 99 & 2133 & 140 & 1906 & 126 & 3320 & 226 & 3349 & 231 & 1713 & 121 & 2592 & 186 & 4790 & 343 & 2273 & 190 \\
\hline $\mathrm{Zr}$ & 44 & 3 & 214 & 14 & 125 & 8 & 127 & 9 & 113 & 8 & 160 & 12 & 77 & 6 & 18 & 2 & 27 & 3 \\
\hline $\mathrm{Nb}$ & 30 & 2 & 173 & 12 & 27 & 2 & 24 & 2 & 39 & 3 & 82 & 6 & 23 & 2 & 2.8 & 0.3 & 25.5 & 2.82 \\
\hline $\mathrm{Sn}$ & 254 & 17 & 353 & 23 & 230 & 15 & 128 & 9 & 261 & 18 & 197 & 14 & 186 & 14 & 87 & 8 & 375 & 36 \\
\hline $\mathrm{Ba}$ & 4.9 & 0.6 & 11.0 & 1.0 & 9.7 & 0.9 & 9.1 & 0.9 & 11.3 & 1.1 & 7.2 & 0.8 & 7.2 & 0.8 & 33.8 & 3.3 & 2.1 & 0.7 \\
\hline $\mathrm{La}$ & 49716 & 3384 & 57613 & 3986 & 46580 & 3257 & 20178 & 1473 & 52134 & 3871 & 64385 & 4963 & 55323 & 4353 & 3020 & 258 & 13205 & 1095 \\
\hline $\mathrm{Ce}$ & 85456 & 6334 & 101377 & 7706 & 84400 & 6522 & 39226 & 3229 & 99035 & 8357 & 121968 & 10852 & 96039 & 8789 & 3993 & 381 & 23997 & 2393 \\
\hline $\operatorname{Pr}$ & 9782 & 706 & 10356 & 765 & 9829 & 737 & 5055 & 402 & 12588 & 1023 & 13125 & 1120 & 11270 & 988 & 453 & 36 & 2730 & 273 \\
\hline $\mathrm{Nd}$ & 36609 & 2865 & 32080 & 2587 & 36785 & 3025 & 15769 & 1396 & 46853 & 4269 & 39120 & 3786 & 38751 & 3871 & 1825 & 142 & 10572 & 1171 \\
\hline $\mathrm{Sm}$ & 5590 & 384 & 2718 & 190 & 5605 & 397 & 3203 & 237 & 6227 & 470 & 3177 & 249 & 4548 & 365 & 414 & 37 & 2930 & 230 \\
\hline $\mathrm{Eu}$ & 55 & 4 & 22 & 2 & 52 & 4 & 50 & 4 & 60 & 5 & 22 & 2 & 47 & 4 & 9 & 1 & 34 & 3 \\
\hline $\mathrm{Gd}$ & 3543 & 247 & 2329 & 165 & 3635 & 261 & 2435 & 184 & 4371 & 336 & 2431 & 195 & 3560 & 292 & 641 & 43 & 2335 & 307 \\
\hline $\mathrm{Tb}$ & 267 & 17 & 155 & 10 & 279 & 18 & 250 & 17 & 408 & 27 & 124 & 9 & 293 & 20 & 119 & 9 & 280 & 28 \\
\hline Dy & 826 & 54 & 685 & 45 & 940 & 62 & 1105 & 75 & 1554 & 106 & 483 & 34 & 1157 & 82 & 916 & 71 & 993 & 81 \\
\hline Ho & 75 & 5 & 92 & 6 & 93 & 6 & 139 & 10 & 156 & 11 & 62 & 5 & 123 & 9 & 177 & 14 & 108 & 12 \\
\hline $\mathrm{Er}$ & 97 & 6 & 167 & 11 & 134 & 9 & 225 & 14 & 221 & 14 & 125 & 8 & 178 & 12 & 312 & 26 & 177 & 16 \\
\hline $\mathrm{Tm}$ & 6.2 & 0.5 & 14.3 & 1.0 & 9.6 & 0.7 & 18.4 & 1.3 & 18.0 & 1.3 & 13.6 & 1.0 & 14.6 & 1.1 & 26 & 2 & 20 & 2 \\
\hline $\mathrm{Yb}$ & 25 & 2 & 71 & 5 & 45 & 3 & 87 & 7 & 98 & 8 & 89 & 7 & 82 & 7 & 95 & 8 & 124 & 13 \\
\hline $\mathrm{Lu}$ & 2.5 & 0.2 & 8.9 & 0.7 & 4.7 & 0.4 & 9.7 & 0.8 & 10.9 & 0.9 & 10.9 & 0.9 & 10.0 & 0.8 & 7 & 1 & 17 & 2 \\
\hline Hf & 4.8 & 0.6 & 10.3 & 1.0 & 9.7 & 0.9 & 14.0 & 1.3 & 12.3 & 1.3 & 10.0 & 1.0 & 6.7 & 0.8 & 1.1 & 0.2 & 2.4 & 0.8 \\
\hline $\mathrm{Ta}$ & 2.2 & 0.2 & 9.9 & 0.7 & 1.1 & 0.1 & 0.4 & 0.1 & 0.9 & 0.1 & 0.9 & 0.1 & 0.3 & 0.1 & 1.5 & 0.2 & 0.5 & 0.1 \\
\hline $\mathrm{Pb}$ & 165 & 11 & 427 & 29 & 193 & 13 & 371 & 26 & 204 & 15 & 227 & 17 & 238 & 18 & 55.2 & 4.8 & 50 & 4 \\
\hline $\mathrm{Th}$ & 1.4 & 0.1 & 17.1 & 1.3 & 1.9 & 0.2 & 2.5 & 0.2 & 18.5 & 1.5 & 10.2 & 0.9 & 2.5 & 0.3 & 1.4 & 0.1 & 201 & 18 \\
\hline $\mathrm{U}$ & 4.6 & 0.4 & 3.3 & 0.3 & 5.6 & 0.5 & 8.7 & 0.7 & 1.4 & 0.2 & 0.6 & 0.1 & 1.6 & 0.2 & 22.6 & 2.2 & 14.0 & 1.4 \\
\hline
\end{tabular}


the epidote-group minerals, as well as for the host granite, are presented in Figs. 9A and 9B. The results obtained through both methods are in good agreement in the range of the L-MREE, which is measurable with EPMA. As expected, the epidote and ferriepidote EPMA-derived patterns are more irregular and subjected to higher analytical uncertainties due to the relatively low REE and Y contents.

The patterns for the ferriallanite-rich compositions show the highest fractionation degrees, with $\mathrm{La}_{\mathrm{N}} / \mathrm{Nd}_{\mathrm{N}}, \quad \mathrm{Sm}_{\mathrm{N}} / \mathrm{Y}_{\mathrm{N}}$ (all data), and $\mathrm{Er}_{\mathrm{N}} / \mathrm{Lu}_{\mathrm{N}}$ (LA-ICP-MS data) ratios varying between 3-4, 40-80 and 2-6; typical allanite has relatively lower fractionated patterns, with ratios between 2-3, 20-60 and 1-2, respectively. Epidote and ferriepidote compositions present the lowest fractionation degrees, with $\mathrm{La}_{N} / \mathrm{Nd}_{\mathrm{N}}$ and $\mathrm{La}_{\mathrm{N}} / \mathrm{Y}_{\mathrm{N}}$ ratios close to unity. Negative Eu anomalies are well developed in all cases, with $0.02<\mathrm{Eu} / \mathrm{Eu}^{*}$ $<0.05\left[\mathrm{Eu}^{*}=\left(\mathrm{Sm}_{\mathrm{N}}{ }^{*} \mathrm{Gd}_{\mathrm{N}}\right)^{0.5}\right]$, the lower values appearing only in ferriallanite. It should be noted that allanite compositions from zone IV, external to the epidote zone, as well as most compositions observed in aggregates made up only of allanite, are significantly richer in MREE (see Fig. 9A), with $\mathrm{La}_{\mathrm{N}} / \mathrm{Nd}_{\mathrm{N}}$ and $\mathrm{Sm}_{\mathrm{N}} / \mathrm{Y}_{\mathrm{N}}$ ratios between 2-3 and 20-40, respectively.

The REE whole rock pattern of the host peralkaline granite (Fig. 9B) is also characterized by a higher fractionation degree in the LREE side. Normalized $\mathrm{La}_{\mathrm{N}} / \mathrm{Nd}_{\mathrm{N}}, \quad \mathrm{Sm}_{\mathrm{N}} / \mathrm{Ho}_{\mathrm{N}}$ and $\mathrm{Er}_{\mathrm{N}} / \mathrm{Lu}_{\mathrm{N}}$ ratios are 2.4 1.5, and 1.0, respectively, with $\mathrm{Eu} /$ $\mathrm{Eu}^{*}=0.04$. Its LREE pattern is controlled mainly by primary chevkinite and the hydrothermal ferriallanite and allanite discussed in this work. Albeit the higher L-MREE chevkinite contents, when compared to ferrriallanite, their patterns are fractionated to a similar degree (Vlach and Gualda 2007). The M-HREE whole rock contents depends on allanite (particularly from zone IV), primary and hydrothermal zircon, as well as late titanite patterns, a theme to be explored in a next contribution.

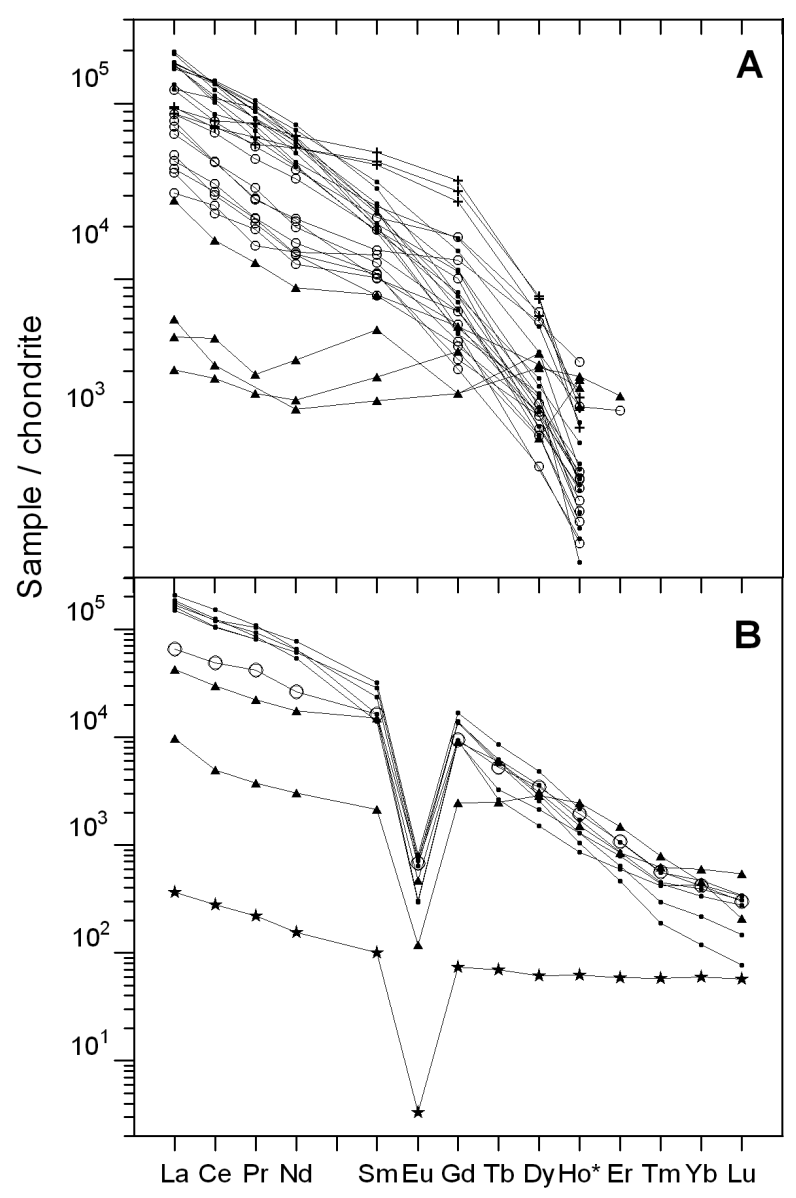

Figure 9. Representative REE patterns for the hydrothermal epidotegroup minerals from the Corupá alkali-feldspar granite. A: EPMA analyses, B: LA-ICP-MS analyses. The REE whole-rock pattern (sample CO-2) is also shown in B. Normalization factors according to Boynton (1984). Ho* stands for Y in EPMA and Ho in LA-ICPMS analyses. Note that A and B scales are different to accommodate the whole rock data in B. Ferriallanite: points; allanite (zone II): open circles; allanite (zone IV): crosses; epidote/ferriepidote: triangles; whole rock: stars. Discussion in the text.

Other trace element patterns are emphasized in the multi-element diagram depicted in Fig. 10. Relatively to the whole rock abundances, ferriallanite is enriched ( $>10$-fold) in $\mathrm{Ti}, \mathrm{Sr}$, and $\mathrm{Ga}$ (up to 90 times) and depleted in $\mathrm{Mg}, \mathrm{Rb}$, Th and $\mathrm{Zr}$ (by a factor of 0.002-0.02). Ga and Mn contents in allanite are lower than in ferriallanite, while $\mathrm{Zr}$, $\mathrm{Ta}, \mathrm{Nb}$ and $\mathrm{U}$ are higher. Relative to ferriallanite and allanite, epidote is enriched in $\mathrm{U}, \mathrm{Sr}$ (up to 
2000-fold) and depleted in $\mathrm{Nb}, \mathrm{Pb}, \mathrm{Zr}, \mathrm{Hf}, \mathrm{Ti}, \mathrm{Zn}$ and Ga. As it is well known, epidote concentrates significant amounts of Sr (e.g. Frei et al. 2004). The measured $\mathrm{Pb}$ contents $(50-430 \mathrm{ppm})$ in the Corupá epidote-group minerals are in great excess in relation to the expected radiogenic $\mathrm{Pb}$ generated by Th (ca. $1.5-200 \mathrm{ppm})$ and $\mathrm{U}(0.5-14 \mathrm{ppm})$ decays. This puts some constraints on allanite $\mathrm{U}-\mathrm{Pb}$ dating. Sn, not represented in Fig. 10, occurs in significant amounts, between 90 and 375 ppm in all these minerals (Table II).

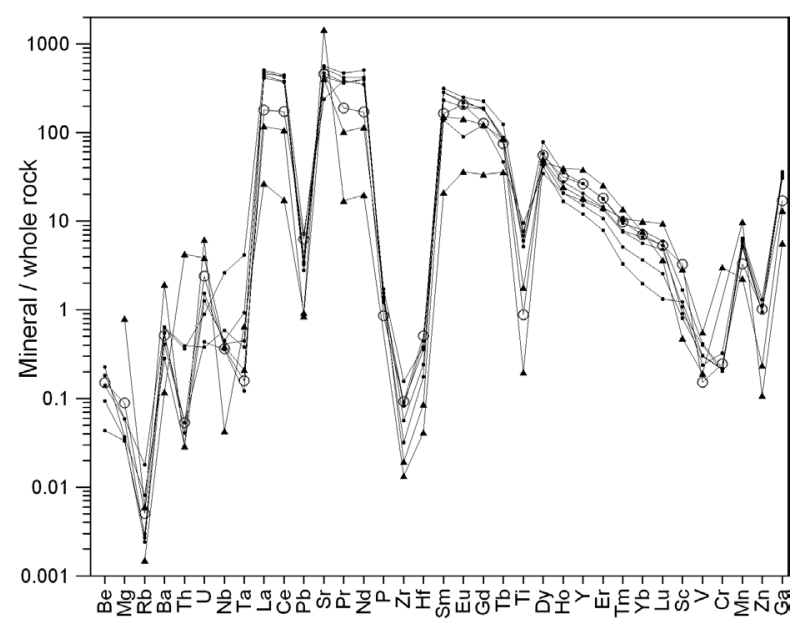

Figure 10. Multi-element diagram showing trace element distribution patterns for hydrothermal ferriallanite, allanite, and epidote, as normalized to the whole host granite composition (sample CO-2). Symbols as in Fig. 9.

\section{DISCUSSION}

MICRO-STRUCTURAL AND COMPOSITIONAL VARIATIONS

The BSE and the compositional X-ray images demonstrate complex zoning patterns in hydrothermal single crystals and crystal aggregates of epidote-group minerals in the Corupá peralkaline granite. In several crystal aggregates, zone I ferriallanite is made of irradiating, thin acicular crystals with swallow-tail terminations, which suggests a relatively fast grow. This ferriallanite was overgrown by common allanite. The external part of the epidote-ferriepidote zone and the most external zone IV constituted by allanite display a somewhat convolute-like zoning pattern. These zones and all internal parts of the epidoteferriepidote zone III are overprinted by thin regular and recurrent compositional zones. The external zone IV is more homogeneous and continuous. Relatively Sr-rich epidote appears filling in interstices among common epidote crystals. This complex pattern suggests contrasted crystallization conditions or rates.

The compositional variation range observed in the hydrothermal epidote-group minerals covers a significant range along the allanite-ferriallanite and epidote-ferriepidote joints. A compositional gap may exist, however, between the more typical compositions of allanite-ferriallanite and epidoteferriepidote in the studied case. In fact, despite the high spatial resolution of the EPMA, some results could represent mixed analyses, a combination of very thin contrasted compositional domains. It must be emphasized that both BSE and compositional images show abrupt and sharp contacts between the allanite and epidote zones. This is intriguing, as literature data point to a compositional continuous between these end-members (e.g. Deer et al. 1986, Gieré and Sorensen 2004), as also indicated by Fig. 3.

The REE patterns of allanite from the internal zones I and II show a higher fractionation of LREE over HREE, while allanite from the external zone IV has a somewhat less fractionated pattern and/ or contains higher MREE abundances. Epidote and ferriepidote present lower fractionation degrees and much lower LREE, and similar or somewhat higher HREE amounts as compared with allanite.

These compositional variations and the recurrence of allanite in the zoning patterns should be a response to local fluctuations in the concentrations of $\mathrm{Ca}, \mathrm{Al}, \mathrm{Fe}^{3+}$ and REE, among other minor elements, due to their preferences for crystallizing 
hydrothermal phases or for the remaining fluid and to chemical refreshment by recurrent fluid input. The higher contents of $\mathrm{Ce}$ and $\mathrm{Ti}$ in the internal allanite zone IV, as compared with the external zone II, indicate significant oversaturation of these elements in the fluid phase prior to the reprecipitation of allanite after epidote-ferriepidote. The REE contrasted patterns may also suggest some kind of structural control on the LREE and HREE A-site occupancies, allowing the preferential entry of HREE in the Sr-, $\mathrm{Fe}^{3+}$ - and Al-rich end-members (cf. Bonazzi and Menchetti 1995).

THE HYDROTHERMAL ENVIRONMENT AND REE BEHAVIOR AND MOBILITY

Epidote-group minerals present a very large stability field (e.g. Franz and Liebscher 2004, Gieré and Sorensen 2004), and the crystallization environment of the Corupá peralkaline granites is poorly constrained in terms of $\mathrm{T}, \mathrm{P}$ and $f_{\text {volatiles }}$ intensive parameters. Geological and petrographical evidences, as well as some geobarometric estimates available for related plutons within the province, indicates magmatic emplacement and crystallization in lower-crustal levels (Gualda and Vlach 2007). Inferences based on experimental data (e.g. Scaillet and MacDonald 2001) suggest possible solidus temperatures for the granites about $670^{\circ} \mathrm{C}$ and, thus, an upper temperature limit for the hydrothermal environment. The occurrence of magnetite, hematite and galena in the hydrothermal assemblage points to relatively high $f_{\mathrm{O} 2}$ values, close to the magnetite-hematite (HM) buffer, under $\mathrm{S}^{2-}$ saturation conditions.

The widespread distribution of hydrothermal allanite and epidote, as well as zircon and fluorite, in the studied peralkaline granites demonstrates the HFSE- and F-enriched nature of the postmagmatic fluids. A common feature related to the evolution of peralkaline liquids in the Graciosa
Province and elsewhere is the abrupt change in their chemical signature as they cross from magmatic to post-magmatic conditions (Salvi et al. 2000, Vlach and Gualda 2007, Graser and Markl 2008, Vilalva and Vlach 2010), a theoretical limit not easily recognized in real rocks. In general, magmatic evolution by crystal fractionation promotes an increase in alkalinity and accentuates the peralkaline character observed in mineral and/ or whole-rock compositions, while in the postmagmatic stage a sudden decrease in the alkalinity is observed, accompanied by the development of $\mathrm{Ca}-, \mathrm{Al}-$ and F-bearing mineral assemblages, with relatively high REE contents. In the Corupá Pluton there is no clear evidence pointing to an external fluid input with the appropriate (HFSE-rich) composition; however a meteoritic contribution to the volatile constituents can not be disregarded.

The increase in the relative abundance of the HFSE in late- to post-magmatic fluids is a well-known phenomena in such environments, as these elements are relatively soluble in Ca-poor, F-bearing peralkaline liquids and fluids (e.g. Salvi and Williams-Jones 1996, Salvi et al. 2000). In these media, the Ca contents of the residual fluids seem to play a fundamental role (Salvi and Williams-Jones 1990, 1996, Boily and Williams-Jones 1994), and even low Ca contents lead to the crystallization of fluorite and a fast decrease of the F activity in the fluid phase. As a consequence, the HFSE solubility decreases and they are preferentially incorporated into the mineral structures.

The main primary repository mineral of LREE in syenites and granites from the Corupá Pluton is chevkinite, a typical accessory phase with REE contents up to 49 wt. \% (REE) $)_{2} \mathrm{O}_{3}$, which is very susceptible to post-magmatic alteration (Vlach and Gualda 2007). Among the related chemical transformations, the authors emphasized a significant increase in $\mathrm{Ti}$ and a decrease in total $\mathrm{Fe}$ and LREE, indicating that these latter elements moved preferentially to the volatile phase. Importantly, REE 
and specially LREE fractionation patterns observed for primary and altered chevkinite are very similar and so must be the pattern acquired by the fluids. It is worth to note also that REE- and F-rich hydrothermal phases are almost absent in the largely dominant metaluminous alkali-feldspar syenites and quartz syenites, with post-magmatic assemblages made up mainly of actinolitic amphibole, phyllosilicates, stilpnomelane, albite and quartz. This indicates that LREE released from chevkinite from syenites concentrates also in the latest fluids percolating granites. Primary chevkinite in syenites and granites is thus a suitable REE source, and its alteration should contribute to the LREE-enriched nature of the late fluids in the Corupá Pluton.

\section{CONCLUSIONS}

The hydrothermal crystallization of epidote-group minerals in peralkaline alkali-feldspar granites from the Corupá Pluton, South Brazil, indicates that the late fluids were relatively rich in HFSE, particularly the LREE. These higher LREE amounts were probably maintained in solution in Ca-poor and F-rich fluids, until the precipitation of fluorite in the evolved granites and consequent decrease in their solubility. The LREE, and also other HFSE, were concentrated mostly by magmatic fractionation in a peralkaline environment, as well as released through the hydrothermal alteration of early formed primary chevkinite. In this sense, these hydrothermal minerals are related mostly to an isochemical redistribution of the REE, specially LREE, during the post-magmatic crystallization stages of the Corupá Pluton.

The remarkable micro-structural and compositional zoning patterns observed in the epidote-group minerals point to contrasting growth conditions and significant compositional variations in the evolving hydrothermal fluid, under oxidizing conditions. The observed variations in the REE fractionation patterns indicates that fluid compositions evolved progressively towards higher MREE/LREE and/or HREE/LREE ratios.

\section{ACKNOWLEDGMENTS}

This work was supported by grants from Fundação de Amparo à Pesquisa do Estado de São Paulo (FAPESP, Proc. 08/00562-0) and Conselho Nacional de Desenvolvimento Científico e Tecnológico (CNPq, Proc. 307583/2008-2). Sandra Andrade gave invaluable assistance during the LA-ICP-MS lab work and $\mathrm{H}$. Ulbrich reviewed a manuscript first draft. Elsevier kindly gave permission to reproduce Fig. 2A.

\section{RESUMO}

Minerais do grupo do epidoto, com albita, quartzo, fluorita, filossilicatos pobres em $\mathrm{Al}$ e ricos em $\mathrm{Fe}$, zircão e quantidades menores de óxidos e sulfetos são fases hidrotermais típicas em álcali-feldpato granitos peralcalinos do Pluton Corupá, Província Graciosa, Sul do Brasil. Os minerais do grupo do epidoto ocorrem como cristais individuais ou agregados que preenchem interstícios e cavidades miarolíticas na rocha. Mostram zonamento complexo, recorrente, descrito por uma zona interna de ferriallanita-(Ce), seguida por allanita(Ce), epidoto-ferriepidoto e uma zona externa com allanita-(Ce), com contatos bruscos em imagens BSE e de raios-X. Os padrões de ETR mostram decréscimo do grau de fracionamento das ETRL em relação às ETRP da ferriallanita para o epidoto. A zona mais externa de allanita é relativamente enriquecida em ETRM. Dados LA-ICPMS, indicam que a ferriallanita é enriquecida ( $>10$ vezes) in $\mathrm{Ti}, \mathrm{Sr}$, and $\mathrm{Ga}$ e emprobrecida em $\mathrm{Mg}, \mathrm{Rb}, \mathrm{Th}$, e Zr. Allanita apresenta conteúdos menores em Ga e Mn e maiores em $\mathrm{Zr}, \mathrm{Nb}, \mathrm{e} \mathrm{U}$, comparada à ferriallanita, enquanto o epidoto é enriquecido em $\mathrm{Sr}$ e $\mathrm{U}$ em empobrecido e $\mathrm{Pb}$, $\mathrm{Zr}$, Th, Ti e Ga. A formação destes minerais é relacionada a concentrações variáveis de HFSEs, $\mathrm{Ca}, \mathrm{Al}, \mathrm{Fe}$ e $\mathrm{F}$ em fluidos reminescente da cristalização magmática em ambientes relativamente oxidantes, próximos ao tampão 
HM. Os ETRL-M foram em parte liberados a partir da alteração de chevkinita, o seu principal repositário nas rochas hospedeiras.

Palavras-chave: allanita, epidoto, hidrotermal, variações composicionais, granito peralcalino, Pluton Corupá, Província Graciosa.

\section{REFERENCES}

ARMBRUSTER T ET AL. 2006. Recommended nomenclature of epidote-group minerals. Eur J Mineral 18: 551-567.

BASTIN GF AND HeIJLIGERS HJM. 1990. Progress in electronprobe microanalysis. Materialwissenschaft und Werkstofftechnik 21: 90-92.

BOILY MAND WILLIAMS-JONES AE. 1994. The role of magmatic and hydrothermal processes in the chemical evolution of the Strange Lake Plutonic Complex (Quebec-Labrador). Contrib Mineral Petrol 118: 33-47.

BonAZZI P AND MENCHETTI S. 1995. Monoclinic members of the epidote group: effects of the $\mathrm{Al} \leftrightarrow \mathrm{Fe}^{+3} \leftrightarrow \mathrm{Fe}^{2+}$ substitution and of the entry of $\mathrm{REE}^{3+}$. Mineral Petrol 53: $133-153$

BONAZZI P, MENCHETTI S AND REINECKE T. 1996. Solid solution between piemontite and androsite-( $\mathrm{La})$, a new mineral of the epidote group from Andros Island, Greece. Am Mineral 81: 735-742.

BOYNTON WV. 1984. Cosmochemistry of the rare earth elements: meteorite studies. In: HENDERSON P (Ed), Rare earth element geochemistry. Amsterdan. Elsevier, p. 63-114.

DEeR WA, HowIE RA AND ZUSSMAN J. 1986. Rock-forming minerals. 1B. Disilicates and ring silicates. $2^{\text {nd }}$ ed., Longman Scientific \& Technical. London, 629 p.

DOLLASE W. 1971. Refinement of the crystal structures of epidote, allanite, and hancockite. Am Mineral 56: 447-464.

DROOP GTR. 1987. A general equation for estimating $\mathrm{Fe}^{3+}$ in ferromagnesian silicates and oxides from microprobe analysis, using stoichiometric criteria. Mineral Mag 51: 431-437.

ERCIT TS. 2002. The mess that is "allanite". Can Mineral 40: 1411-1419.

EXLEY RA. 1980. Microprobe studies of REE-rich accessory minerals: implications for Skye granite petrogenesis and REE mobilty in hydrothermal systems. Earth Planet Sci Lett 48: 97-110.

Franz G AND LIEBSCher A. 2004. Physical and chemical properties of the epidote minerals - An introduction. In: LIEBSCHER A AND FRANZ G (Eds), Epidotes. Rev Miner Geochem 56: 1-82.

Frei D, Liebscher A, Franz G AND Dulski P. 2004. Trace element geochemistry of epidote minerals. In: LIEBSCHER A AND FRANZ G (Eds), Epidotes. Rev Miner Geochem 56: 553-605.
GaO S, Liu X, Yuan H, Hattendorf B, Gunther D AND Hu S. 2002. Determination of forty two major and trace elements in SGS and NIST SRM glasses by laser ablation-inductively coupled plasma-mass spectrometry. J Geostand Geoanal 26: 181-196.

GARIN Y, VLACH SRF AND TASSINARI CCG. 2003. Sr and Nd isotope signatures of A-type alkaline syenites, granites, and associated diorites and hybrid rocks from the Corupá Massif (SC), Serra do Mar Province, S Brazil. In: SOUTH AMERICAN SYMPOSIUM ON ISOTOPE GEOLOGY, 4, Salvador, Brazil 2: 556-559.

GIERÉ R AND SORENSEN SS. 2004. Allanite and other REE-rich epidote-group minerals. In: LIEBSCHER A AND FRANZ G (Eds), Epidotes. Rev Miner Geochem 56: 431-493.

GRASER G AND MARKL G. 2008. Ca-rich ilvaite-epidotehydrogarnet endoskarns: A record of late-magmatic fluid influx into the persodic Ilímaussaq Complex, South Greenland. J Petrol 49: 239-265.

GUALDA GAR AND VLACH SRF. 2007. The Serra da Graciosa A-type Granites \& Syenites, southern Brazil. Part 1: Regional setting and geological characterization. An Acad Bras Cienc 79: 405-430.

Hoshino M, Kimata M, Shimizu M, Nishida N AND FUJIWARA T. 2006. Allanite-(Ce) in granitic rocks from Japan: genetic implications of patterns of REE and Mn enrichment. Can Mineral 44: 45-62.

JIANG N. 2006. Hydrothermal alteration of chevkinite-(Ce) in the Shuiquangou syenitic intrusion, northern China. Chem Geol 227: 100-112.

Kartashov PM, Ferraris G, IVAldi G, SoKolova E AND MCCAMMON CA. 2002. Ferriallanite-(Ce), $\mathrm{CaCe} \mathrm{Fe}^{3+} \mathrm{AlFe}^{2+}$ $\left(\mathrm{SiO}_{4}\right)\left(\mathrm{Si}_{2} \mathrm{O}_{7}\right) \mathrm{O}(\mathrm{OH})$, a new member of the epidote group: description, X-ray and Mössbauer study. Can Mineral 40: 1641-1648.

PetrícK I, Broska I, LIPKA J AND SimAn P. 1995. Granitoid allanite-(Ce); substitution relations, redox conditions and REE distributions (on an example of I-type granitoids, Western Carpathians, Slovakia). Geol Carpath 46: 79-94.

POITRASSON F. 2002. In situ investigations of allanite hydrothermal alteration: examples from calc-alkaline and anorogenic granites of Corsica (southeast France). Contrib Mineral Petrol 142: 485-500.

Prazeres Filho HJ, Harara OMM, BASEI MAS, PASSARELli CR AND SIGA JR O. 2003. Litoquímica, Geocronologia $\mathrm{U}-\mathrm{Pb}$ e Geologia Isotópica (Sr-Nd-Pb) das Rochas Graníticas dos Batólitos Cunhaporanga e Três Córregos na Porção Sul do Cinturão Ribeira, Estado do Paraná. Geologia USP (Sér. Cient.) 3: 51-70.

SALVI S, FONTAN F, MONXHOUX P, WiLliams-JONES AE AND MoINE B. 2000. Hydrothermal mobilization of high field strength elements in alkaline igneous systems: evidence from theTamazeght complex (Morocco). Econ Geol 95: 559-676. 
SALVI S AND WiLliams-JonES AE. 1990. The role of hydrothermal processes in the granite-hosted Zr, Y, REE deposit at Strange Lake, Quebec/Labrador: Evidence from fluid inclusions. Geochim Cosmochim Acta 54: 2403-2418.

SALVI S AND WiLliams-JoneS AE. 1996. The role of hydrothermal processes in concentrating high-field strength elements in the Strange Lake peralkaline complex, northeastern Canada. Geochim Cosmochim Acta 60: 1917-1932.

ScAillet D AND Macdonald R. 2001. Phase relations of peralkaline silicic magmas and petrogenetic implications. J Petrol 42: 825-845.

SCHMIDT MW AND POLI S. 2004. Magmatic epidote. In: LIEBSCHER A AND FRANZ G (Eds), Epidotes. Rev Miner Geochem 56: 399-430.

Sial AN, Toselli AJ, SAaVedra MA AND Ferreira VP. 1999. Emplacement, petrological and magnetic susceptibility characteristics of diverse magmatic epidote-bearing granitoid rocks in Brazil, Argentina and Chile. Lithos 46: 367-392.

VAN ACHTERBERGH E, RAYAN CG AND GRIFFIN WL. 2007. Glitter User's manual. On line interactive data reduction for the LA-ICPMS microprobe v. 4.4 - Gemoc National Key Centre McQuarie University, Australia, 30 p.
VILALVA FCJ AND VLACH SRF. 2010. Major and trace-element composition of REE-rich turkestanite from peralkaline granites of the Morro Redondo Complex, Graciosa Province, South Brazil. Mineral Mag 74: 645-658.

VLACH SRF AND GUALDA GAR. 2007. Allanite and chevkinite in A-type granites and syenites of the Graciosa Province, southern Brazil. Lithos 97: 98-121.

VLACH SRF, JANASI VA AND VASCONCELlOS ACBC. 1990. Associated calc-alkaline and aluminous A-type late Brasiliano granitoids in the States of São Paulo and Paraná, southern Brazil. In: BRAZILIAN CONGRESS OF GEOLOGY, 36, Natal, Brazil 4: 1700-1711.

Vlach SRF, Siga JR O, HARARA OMM, GUALDA GAR, BASEI MAS AND VILALVA FCJ. 2011. Crystallization ages of the A-type magmatism of the Graciosa Province (Southern Brazil): Constraints from zircon U-Pb (IDTIMS) dating of coeval K-rich gabbro-dioritic rocks. J South Am Earth Sci 32: 407-415.

Wood SA AND RicketTS A. 2000. Allanite-(Ce) from the Eocene Castro granite, Idaho: response to hydrothermal alteration. Can Mineral 38: 81-100.

ZEN E-AN AND HAMMARSTON JM. 1984. Magmatic epidote and its petrological significance. Geology 12: 515-518. 